\title{
Isolation and identification of the same type LMG1242 of biosurfactant-producing strain of Pseudomonas aeruginosa from different oil contaminated soils
}

\author{
Farideh Ghavipanjeh ${ }^{\mathrm{a}^{*}}$, Ghasem Moradia, \\ ${ }^{a}$ Environment Group, Department of Energy, Materials and Energy Research Center, Tehran, Iran \\ ${ }^{b}$ Iran Young Researchers and Elites Club
}

Received 7th January 2019 / Accepted 7th November 2019

\begin{abstract}
Emulsification is a major rate limiting step in any biological conversion of heavy hydrocarbons. Here, thirty bacterial strains were isolated from seven native consortia and screened for biosurfactantproducing activities which could enhance emulsification of heavy oils. The consortia were obtained by sampling from oil contaminated soils of different petroleum refineries of Iran. The oil spreading test, drop collapse test, emulsification index (E24) and surface tension measurements were used to evaluate the biosurfactant producing activities of the strains. A total number of 5 strains out of 30 were finally selected as the best biosurfactant-producing bacteria. The clear zone diameters in their oil spreading test were 4 to $5 \mathrm{~cm}$, and E24 were 48 to $92 \%$. The selected strains also properly lowered the surface tensions of the supernatants to $23.5-32 \mathrm{mN} / \mathrm{m}$ when grown on heavy diesel. All the selected strains were identified by 16S rRNA sequencing analysis as Pseudomonas aeruginosa LMG1242 (99.9\% homology) which is a newly isolated type in oil polluted soils. The results suggest P. aeruginosa LMG1242 as a predominant and highly active biosurfactant producing bacterium which could be further evaluated in petroleum bioremediation and bioprocessing applications.
\end{abstract}

Keywords: $P$. aeruginosa, biosurfactant, emulsification, bioconversion, hydrocarbons, heavy oils

\section{INTRODUCTION}

Biosurfactans are mainly produced by microorganisms including different genera of bacteria and yeasts (Desai \& Banat, 1997; Amaral et al., 2011). They belong to a structurally diverse group of surface active molecules which increase the surface area of hydrophobic substances, increase the bioavailability of hydrophobic substrates, and also regulate the adhesion of microorganisms to surfaces (Rosenberg \& Ron, 1999). These molecules contain hydrophobic and hydrophilic moieties that reduce surface tension and interfacial tensions between individual molecules at the surface and interface (Cooper, 1986).

The largest application of biosurfactant is the oil industry due to hydrophobicity of hydrocarbons (Bannat, 2000). They have been used in applications such as; enhanced oil recovery, oil spill bioremediation and removal of oil sludge from storage tanks (Mulligan, 2005). Crude oils and petroleum products contain thousands of hydrocarbons of different chain

\footnotetext{
*Author for correspondence: Farideh Ghavipanjeh, Environment Group, Department of Energy, Materials and Energy Research Center, Tehran, Iran. Email - fghavipanjeh@merc.ac.ir
} 
lengths with low solubility in water. It is known that the availability of particular compounds is a major rate limiting factor in biodegradation rate of oils rather than the chemical structure of the compounds (Sugiura et al., 1997). Also, previous research mainly indicates that biosurfactants are more effective than chemical surfactants in enhancing the solubility and biodegradation rate of petroleum hydrocarbons (Chrzanowski et al., 2008; Cybulski et al., 2003; Souza et al., 2014). Biosurfactants increase the bioavailability of hydrocarbons by emulsification of the oil phase resulting in enhanced bacterial growth and bioconversion. This reveals the importance of identifying microorganisms responsible for biosurfactant production and emulsification of hydrocarbons in biological conversions.

Much research is conducted to identify biosurfactant-producing bacteria from different environments in contact with different hydrocarbon oils mainly for the purpose of bioremediation and biodegradation as well as enhanced oil recovery (Christova et al., 2019; Cai et al., 2017; Nwagumal et al., 2016; Souza et al., 2014; Bach \& Gutnick, 2004). However, fewer reports are available on identification of biosurfactant-producing bacteria and their role in hydrocarbon bioprocessing applications such as viscosity reduction and heavy oil upgrading (Gudiña \& Teixeira, 2017; Cerón-Camacho et al., 2013; Perfumo et al., 2010). Rocha et al. (2000) used Pseudomonas aeruginosa (USB-CS1) in making stabilized emulsions of heavy hydrocarbons getting proper viscosity reduction at ambient temperature. Viscosity reduction enables better properties for transportation and processing of the oils.

In our previous research, we obtained several microbial consortia from oil contaminated soils capable of bioconversion of heavy hydrocarbons (Ghavipanjeh et al., 2015; Ghollami et al., 2013; Ghavipanjeh et al., 2008). The consortia were able to increase the saturated fractions and decrease the resin fractions of the heavy oils thus improving the quality of the heavy oils. This happened through significant emulsification of the oils. However, the emulsification activities and consequently the performance of the consortia were sharply decreased after several passages and storage at $-20^{\circ} \mathrm{C}$. This revealed the loss of biosurfactant-producing bacteria or their activities upon preservation. It is expected that the addition of native strains to the consortia may stimulate biological conversion rates by enhancing the substrates availability to microorganisms and so lower mass transfer limitation (Abalos et al., 2004; Aparna et al., 2011). This could also impose a broader range of microorganisms to the consortia enabling them to convert a broader range of hydrocarbons (Barin et al., 2014).

The objective of this research was to isolate native biosurfactant-producing species which could be effectively used to facilitate the bioconversion rate of heavy hydrocarbons in bioremediation and bioconversion processes. Here, native bacterial cultures were obtained from soil samples and adapted on heavy hydrocarbon oils. The consortia were screened for biosurfactant-producing properties by qualitative and quantitative methods. Pure bacterial strains were then isolated from the selected consortia and examined for biosurfactant-producing properties. The best isolates were then identified by $16 \mathrm{~S}$ rRNA sequencing analysis.

\section{MATERIALS AND METHODS}

\section{Sampling}

Twelve soil samples were taken from highly aged oil spilled sites of different refineries of Iran including: Arak (AR1 to AR3 samples), Abadan (AH1 to AH3 samples), Shiraz (SH1 to SH3 samples) and Isfahan (IS1 to IS3 samples) refineries. The sampling was carried out in the spring 2016. The sampling locations are shown in Figure 1.

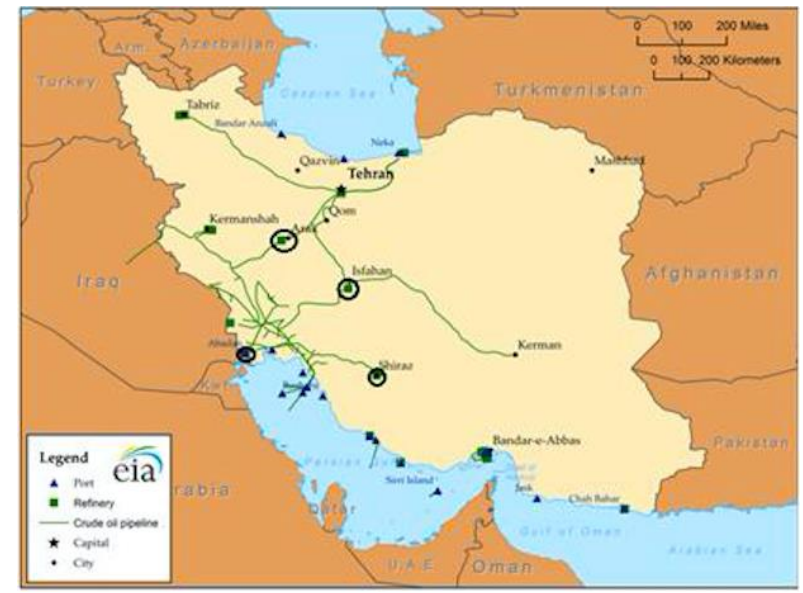

Figure 1. Sampling locations. 


\section{Substrates and chemicals}

Heavy diesel and Isofeed were supplied by Isfahan refinery and used as the substrates to grow the consortia and the pure strains. Isofeed is a heavy end cut of vacuum distillation process in petroleum refineries. It is the feed going through Isomax unit process that is a catalytic cracking process for conversion of heavy hydrocarbons mainly to gasoline at a high pressure and temperature. Table 1 indicates the properties of the Isofeed and heavy diesel used for the experiments. The chemicals used for preparation of the culture media and experimental tests were of analytical grade produced by Merck.

Table 1. Characteristics of Isofeed and heavy diesel from Isfahan refinery.

\begin{tabular}{ccc}
\hline Parameter & Isofeed & Heavy diesel \\
\hline $\begin{array}{c}\text { Density at } \\
15^{\circ} \mathrm{C}\left(\mathrm{g} / \mathrm{cm}^{3}\right)\end{array}$ & 0.9 & 0.86 \\
\hline $\begin{array}{c}\mathrm{K} . \mathrm{Viscosity} \\
\left.\times 10^{-6} \mathrm{~m}^{2} / \mathrm{s}\right)\end{array}$ & 6.19 at $100^{\circ} \mathrm{C}$ & 2.5 at $37.5^{\circ} \mathrm{C}$ \\
\hline $\begin{array}{c}\text { Flash point } \\
\text { min. }\left({ }^{\circ} \mathrm{C}\right)\end{array}$ & 210 & 64 \\
\hline $\begin{array}{c}\text { Pour point } \\
\text { max. }\left({ }^{\circ} \mathrm{C}\right)\end{array}$ & 33 & -3 \\
\hline $\begin{array}{c}\text { Total sulfur } \\
\text { content }(\mathrm{wt} \%)\end{array}$ & 1.6 & 1 \\
\hline $\begin{array}{c}\text { Distillation } \\
\text { range }\left({ }^{\circ} \mathrm{C}\right)\end{array}$ & $320-560$ & $170-385$ \\
\hline
\end{tabular}

\section{Culture media}

A mineral salt medium (MSM) was used to cultivate the bacterial consortia and stains (Bushnell and Hass, 1941). The MSM medium contained (g/l): $\mathrm{K}_{2} \mathrm{HPO}_{4}$ (2.75), $\mathrm{KH}_{2} \mathrm{PO}_{4}$ (2.25), $\left(\mathrm{NH}_{4}\right)_{2} \mathrm{SO}_{4}$ (1), $\mathrm{MgSO}_{4} .7 \mathrm{H}_{2} \mathrm{O}$ (0.2), $\mathrm{NaCl}(0.1)$, $\mathrm{FeCl}_{3} \cdot 6 \mathrm{H}_{2} \mathrm{O}(0.02)$, and $\mathrm{CaCl}_{2} \cdot 2 \mathrm{H}_{2} \mathrm{O}(0.01)$.

\section{Consortia enrichment}

In order to prepare the consortia, 5 gram of each soil sample was added into $50 \mathrm{ml}$ MSM culture medium containing $5 \% \mathrm{v} / \mathrm{v}$ heavy diesel oil as the only carbon source. The $\mathrm{pH}$ was adjusted to 6.8. The cultures were kept on a shaking incubator at $160 \mathrm{rpm}$ and $30^{\circ} \mathrm{C}$ for 4 days. At the end of this time, $5 \mathrm{ml}$ of the aqueous phase was transferred into another flask containing MSM medium with the same amount of heavy diesel as the second enrichment culture. The samples were incubated once again at the previous conditions for 4 days.
The subculturing procedure was repeated two more times. Each sample was prepared in triplicate to reduce the variation of results. The enrichment cultures were then kept in a refrigerator for the next experiments.

\section{Isolation of pure bacteria}

Bacterial isolations were made by streaking method on nutrient agar, MSM with a top layer of diesel oil, and by pore plate method. The morphologically distinct bacteria were selected for screening biosurfactant-producing bacteria. The isolates were cultured in nutrient broth medium and kept at $30^{\circ} \mathrm{C}$ and $160 \mathrm{rpm}$ in a shaking incubator. The optical densities (OD) of the cultures were measured at wavelength of $660 \mathrm{~nm}$. The cultures were used for inoculation into the MSM medium containing heavy diesel oil when $\mathrm{OD}_{660}$ of the samples, reached to 1 .

\section{Screening methods for detection of biosurfactant producers}

The consortia and the isolates were screened for biosurfactant-producing properties using the most common qualitative and quantitative methods (Bodour \& Miller-Major, 1998; Youssef et al., 2004). The implemented test methods here are drop collapse test, oil spreading test, emulsification index and surface tension measurements.

\section{Drop collapse test}

For the drop collapse method, $2 \mu \mathrm{l}$ of mineral oil was added to each well of a 96-well microtiter plate lid. The lid was equilibrated for $1 \mathrm{~h}$ at room temperature, and consequently $5 \mu$ l of the culture was delivered to center of the oil surface (Bodour \& Miller-Maier, 1998). The shape of the drop on the surface of the oil was inspected after $1 \mathrm{~min}$. Biosurfactant-producing cultures gave flat drops with scoring system ranging from ' + ' to ' ++++ ' corresponding from partial (poor) to complete (excellent) spreading on the oil surface. The sign ‘_ indicates no spreading effect while complete spreading means high biosurfactant producing activity.

\section{Oil spreading method}

Distilled water $(20 \mathrm{ml})$ was added to a Petri dish (10 cm diameter), followed by the addition of 10 $\mu l$ of crude oil to the surface of water. A $10 \mu$ l of 
biosurfactant solution was then added to the oil surface. The diameter of the clear zone formed on the oil surface was measured (Youssef et al., 2004).

\section{Emulsification index}

The cell-free culture broth was used to determine the emulsification capacity. $2 \mathrm{ml}$ of cell-free supernatant was added to $2 \mathrm{ml}$ of kerosene as the hydrophobic source and mixed in a vortex for 2 min. The mixture was stayed for $24 \mathrm{~h}$ and the height of emulsion layer was then measured. The emulsifying index (E24) was calculated as the percent of emulsion height to the total height of solution according to Cooper and Goldenberg (1987).

\section{Surface tension measurements}

The isolates were individually grown in heavy diesel and Isomax feed as the only carbon source, at $30^{\circ} \mathrm{C}$ and $160 \mathrm{rpm}$ in a shaking incubator for one week. The cell-free supernatants were used to measure surface tensions by Kruss Tensiometer model K11. The measurements were made at $25^{\circ} \mathrm{C}$ and reported in $\mathrm{mN} / \mathrm{m}$ (millinewton per meter).

\section{Bacterial identification method}

The selected biosurfactant-producing strains were identified by $16 \mathrm{~S}$ rRNA sequencing analysis. The analysis was performed by ChromasPro software and the data was compared with EzBioCloud database.

\section{Experimental procedures}

\section{Screening of biosurfactant-producing consortia}

The prepared consortia (36 cultures, 3 from each soil sample) were cultured in MSM medium containing heavy diesel oil $(5 \% \mathrm{v} / \mathrm{v})$ and kept at $30^{\circ} \mathrm{C}$ and $160 \mathrm{rpm}$ for one week. An identical flask was also prepared as the blank without any microorganisms and kept at the same situations as the others. The enrichment cultures were investigated by visual observations after incubation. Almost all samples had shown visual alteration of the organic and aqueous phases indicating the growth of microorganisms. Therefore, all the samples were subjected to further examinations. The aqueous phases were separated from the organics and investigations were made on the supernatants. The biosurfactant-producing properties were first investigated by the oil spreading test. It is an easy and rapid test and also there is a strong correlation between oil spreading test and surface tension lowering (Youssef et al., 2004). The selected bacterial cultures were then subjected to drop collapse and E24 tests as complementary tests. The tests were implemented triplicates and presented as mean with standard deviations $( \pm \mathrm{SD})$. The selected consortia were subjected to bacterial isolation and identification of the best biosurfactant-producing strains.

\section{Screening and identification of biosurfactant- producing isolates}

All isolated strains were cultured in MSM medium containing heavy diesel oil $(5 \% \mathrm{v} / \mathrm{v})$ and kept at $30^{\circ} \mathrm{C}$ and $160 \mathrm{rpm}$ for one week. An identical flask was also prepared as the blank without any microorganism. The oil spreading test, drop collapse test and E24 test were implemented as initial tests on the supernatants in order to identify the biosurfactant-producing bacteria. The tests were implemented triplicate and presented as mean with standard deviations $( \pm \mathrm{SD})$. The best performed strains were selected as the best biosuractant-producing strains and then subjected to surface tension measurements and bacterial identification by $16 \mathrm{~S}$ rRNA gene sequence analysis.

\section{RESULTS AND DISCUSSION}

\section{Screening of biosurfactant-producing consortia}

Based on the initial oil spreading and drop collapse tests on the 36 prepared consortia, 7 consortia signified most effective in biosurfactant-producing activities for which E24 tests were then implemented. Figure 2 shows the implemented oil spreading and E24 tests for AR2 consortium. As the figure shows the clear zone in oil spreading test can be observed as the empty interior circle. Also, the emulsified height can be observed in Figure 2-B as the upper layer (beneath a thin layer of oil on top) compared to the blank (Figure 2-A) in which the whole oil phase is on top. 
The results of the implemented tests on the 7 selected consortia are indicated in Table 2 . We know that the diameter of clear zone in oil spreading test is directly proportional to the concentration of biosurfactants in the medium (Morikawa, 2000). The diameter of clear zone for surfactin as an efficient biosurfactant was reported about $5.5 \mathrm{~cm}$ at concentration of 2000 $\mathrm{mg} / 1$ (Youssef et al., 2004). As shown in Table 2, these values are about 6.5 to $7.8 \mathrm{~cm}$ for the selected consortia representing high surface activities of the consortia. The E24 tests are also greater than $50 \%$ indicating high emulsification activities. However, the drop collapse tests are well not consistent with the other two tests e.g. for IS3 in which the drop collapse test is poor but the others tests are quite good.

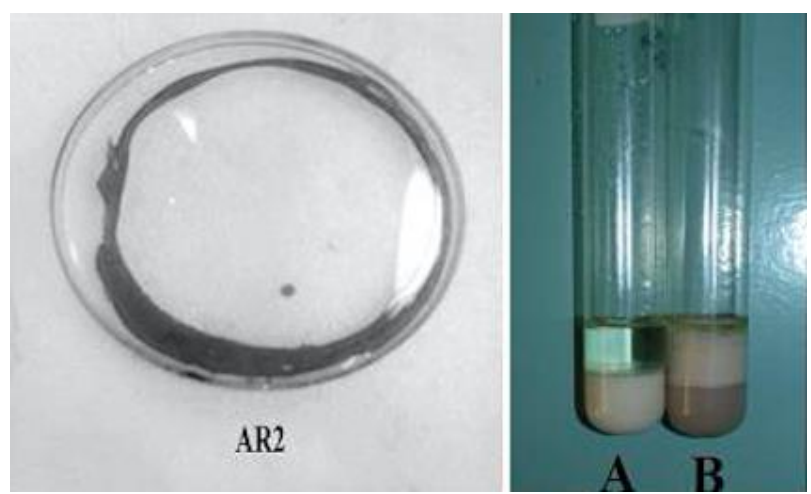

Figure 2. Implemented oil spreading and E24 tests for AR2 consortium.

Table 2. The emulsification activities (E24) of the selected consortia (mean $\pm \mathrm{SD}$ ).

\begin{tabular}{cccc}
\hline $\begin{array}{c}\text { Name of } \\
\text { consortia }\end{array}$ & $\begin{array}{c}\text { Oil } \\
\text { spreading } \\
\text { (cm) }\end{array}$ & $\begin{array}{c}\text { Drop- } \\
\text { collapse }\end{array}$ & E24 (\%) \\
\hline AH1 & $6.8 \pm 0.65$ & + & $50 \pm 1.4$ \\
AR1 & $7.8 \pm 0.76$ & +++ & $83 \pm 3.5$ \\
AR2 & $6.5 \pm 0.5$ & +++ & $75 \pm 2.1$ \\
IS2 & $7.3 \pm 0.29$ & ++ & $50 \pm 1.5$ \\
IS3 & $7.3 \pm 0.29$ & + & $66 \pm 1.8$ \\
SH1 & $7.0 \pm 0.5$ & ++ & $75 \pm 2.2$ \\
SH2 & $7.8 \pm 0.58$ & +++ & $50 \pm 1.6$ \\
\hline + Poor & & & \\
++ Good & & & \\
+++ Very good & & &
\end{tabular}

\section{Screening of biosurfactant-producing isolates}

A total of 30 morphologically different strains were isolated from the seven selected consortia. Table 3 shows the number and name of pure strains isolated from each consortium. The oil spreading test revealed 14 strains positive for biosurfactant productions which were then subjected to other tests. Table 4 shows the results of oil spreading, drop collapse and E24 tests for the 14 preferred strains. Some of the strains showed very little or no emulsification index and almost negative drop collapse test and weak oil spreading at the same time. Five strains which are highlighted in Table 4 exhibited better results compared to the others for at least two tests out of 3. The selected strains included AR1-A, AR2B, SH1-A, SH2-A and SH2-C which were obtained from soil samples of Arak and Shiraz refineries. The clear zones for these strains are about 4 to $5 \mathrm{~cm}$ and E24 results are in the range of $48 \%$ to $92 \%$. A comparison of the results with that of the consortia reveals reductions in oil spreading test while the emulsification activities (E24) are better for most of the selected strains.

Table 3. The numbers and names of bacterial strains isolated from the selected native consortia.

\begin{tabular}{ccc}
\hline $\begin{array}{c}\text { Name of } \\
\text { consortia }\end{array}$ & $\begin{array}{c}\text { No. of isolated } \\
\text { strains }\end{array}$ & $\begin{array}{c}\text { Names of } \\
\text { isolates }\end{array}$ \\
\hline AR1 & 6 & $\begin{array}{c}\text { AR1-A, AR1-B, } \\
\ldots, \text { AR1-F }\end{array}$ \\
\hline AR2 & 6 & $\begin{array}{c}\text { AR2-A, AR2-B, } \\
\ldots, \text { AR2-F }\end{array}$ \\
\hline SH1 & 5 & $\begin{array}{c}\text { SH1-A, SH1-B, } \\
\ldots, \text { SH1-F }\end{array}$ \\
\hline SH2 & 4 & $\begin{array}{c}\text { SH2-A, SH2-B, } \\
\text { SH2-C, SH2-D }\end{array}$ \\
\hline IS2 & 2 & $\begin{array}{c}\text { IS2-A, IS2-B } \\
\text { IS3 }\end{array}$ \\
\hline AH1 & 3 & $\begin{array}{c}\text { IS3-A, IS3-B, } \\
\text { IS3-C }\end{array}$ \\
\hline 4 & $\begin{array}{l}\text { AH1-A, AH1-B, } \\
\text { AH1-C, AH1-D }\end{array}$ \\
\hline
\end{tabular}

Table 5 shows the surface tensions lowering results of the selected strains when grown in two different hydrocarbon substrates (Isofeed and heavy diesel). The surface tension of distilled water at $25^{\circ} \mathrm{C}$ is about $72 \mathrm{mN} / \mathrm{m}$. A good surfactant reduces the surface tension below 30 $\mathrm{mN} / \mathrm{m}$ (Chrzanowski, 2008). The selected strains changed the surface to $23.5-32 \mathrm{mN} / \mathrm{m}$ when grown in heavy diesel and to 32.9-41.8 when grown in Isofeed. This indicates high biosurfactant-producing activities of the selected pure strains. The results are comparable with what obtained by Das and Mukherjee (2007) although, superior for AR2-B $(23.5 \mathrm{mN} / \mathrm{m}$ surface tension). 
Table 5 also shows that the surface tensions of the supernatants are smaller when the bacteria grown on heavy diesel than that of Isofeed. This presumes the reduction of biosurfactant production due to reduction of bacterial activities in heavier hydrocarbons.

Table 4. The results of emulsification activity tests on the preferred isolates.

\begin{tabular}{cccc}
\hline $\begin{array}{c}\text { Name of } \\
\text { sample }\end{array}$ & $\begin{array}{c}\text { Oil } \\
\text { spreading } \\
\text { test } \mathbf{( c m )}\end{array}$ & $\begin{array}{c}\text { Drop } \\
\text { collapse } \\
\text { test }\end{array}$ & $\begin{array}{c}\text { E24 test } \\
\mathbf{( \% )}\end{array}$ \\
\hline AR1-A & $\mathbf{5} \pm \mathbf{0 . 5 8}$ & +++ & $\mathbf{4 8 \pm 1 . 5}$ \\
AR1-B & $2 \pm 0.58$ & - & 0 \\
AR2-A & $5.5 \pm 0.50$ & ++ & $32 \pm 2.4$ \\
AR2-B & $\mathbf{4 . 5 \pm 0 . 4 3}$ & +++ & $\mathbf{8 8 . 8} \pm \mathbf{3 . 1}$ \\
AR2-C & $2.5 \pm 0.76$ & - & 0 \\
AR2-D & $2 \pm 0.00$ & - & 0 \\
SH1-A & $\mathbf{4} \pm \mathbf{0 . 6 5}$ & ++++ & $\mathbf{8 9 . 6 \pm 2 . 8}$ \\
SH1-B & $4 \pm 0.00$ & - & $48 \pm 2.6$ \\
SH2-A & $\mathbf{5} \pm \mathbf{0 . 6 7}$ & +++ & $\mathbf{9 2 \pm 1 . 8}$ \\
SH2-B & $2 \pm 0.33$ & - & $16 \pm 1.5$ \\
SH2-C & $4.5 \pm 0.28$ & +++ & $\mathbf{5 6} \pm 1.2$ \\
IS2-A & $2.5 \pm 0.29$ & - & $8 \pm 1.0$ \\
IS3-A & $3.5 \pm 0.76$ & + & 0 \\
AH1-A & $3.5 \pm 0.29$ & ++ & $48 \pm 1.8$ \\
\hline - No activity & & & \\
+ Poor & & & \\
++ Good & & & \\
+++ Very good & & & \\
++++ Excellent & & &
\end{tabular}

\section{Identification of the suitable species}

Figure 3 shows the phylogenic tree of AR2-B strain. The phylogenic trees of the other selected strains including; AR1-A, SH1-A, SH2-A and $\mathrm{SH} 2-\mathrm{C}$ (not shown here) were exactly the same as AR2-B. All the strains were identified as $P$. aeruginosa LMG1242 by $16 \mathrm{~S}$ rRNA sequence analysis with $99.9 \%$ homology. Although, the visual and physical characteristics such color, emulsification tests and surface tension measurements of the strains were somehow different. It is known that the 16S rRNA gene sequence database may miss diversity in microbial products (e.g. biosurfactants, antibiotics) when identifying closely related isolates (Bodour et al., 2003). In addition, Choi et al. (2013) stated that the common molecular and serological methods may cause critical defects in the diagnosis and identification of $P$. aeruginosa strains. Yet, the results suggest $P$. aeruginosa LMG1242, as a predominant and active strain of bio-surfactant producing bacteria in the examined petroleum contaminated. $P$. aeruginosa species are greatly characterized for rhamnolipids production which exhibit surface actions (Sobri et al., 2018; Wasoh et al., 2017; Nordin et al., 2013; Rashedi et al., 2005). They are identified and investigated in many oil bioremediation activities indicating versatility and large capabilities of these species.

Table 5. The surface tensions measurements of selected isolates grown on heavy diesel and Isofeed.

\begin{tabular}{ccc}
\hline $\begin{array}{c}\text { Name of } \\
\text { isolate }\end{array}$ & $\begin{array}{c}\text { Surface } \\
\text { tension } \\
(\mathbf{m N} / \mathbf{m}, \\
\text { heavy diesel } \\
\text { oil) }\end{array}$ & $\begin{array}{c}\text { Surface } \\
\text { tension } \\
\text { (mN/m, } \\
\text { Isofeed) }\end{array}$ \\
\hline AR1-A & $32 \pm 0.53$ & $35.7 \pm 0.76$ \\
AR2-B & $23.5 \pm 0.61$ & $32.9 \pm 0.57$ \\
SH1-A & $28.6 \pm 43$ & $34 \pm 0.33$ \\
SH2-A & $29 \pm 0.42$ & $33 \pm 0.28$ \\
SH2-C & $30.5 \pm 0.36$ & $41.8 \pm 0.45$ \\
\hline
\end{tabular}

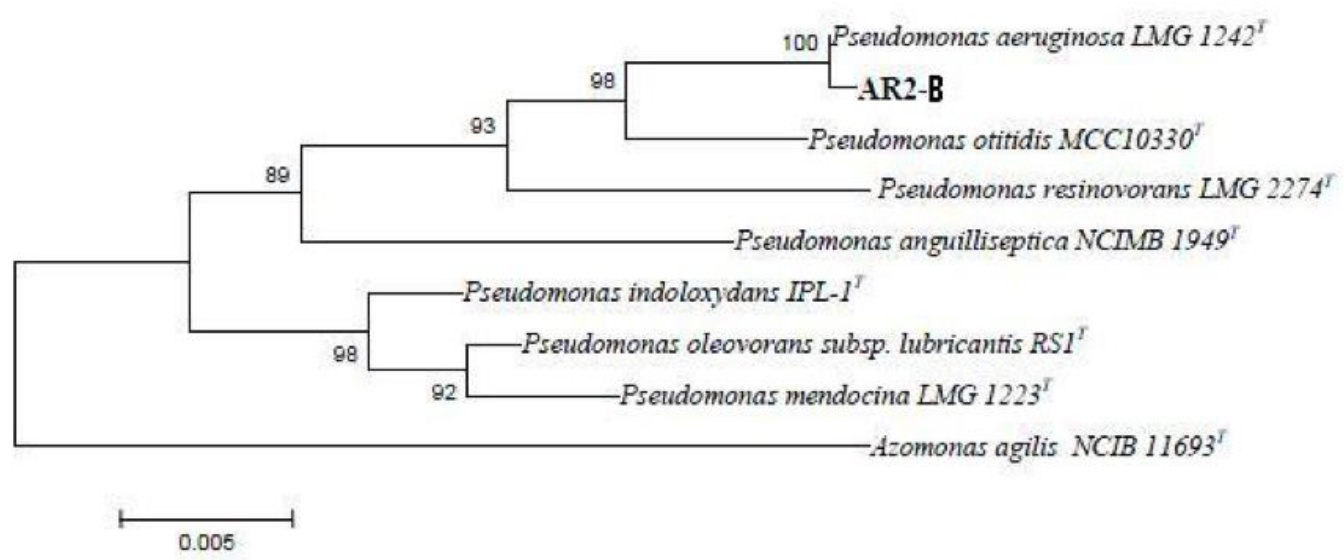

Figure 3. Phylogenetic tree of AR2-B strain. 


\section{CONCLUSION}

Five bacterial strains were isolated from oil contaminated soils of different geographical locations of Iran and all identified as Pseudomonas aeruginosa LMG1242 by $16 \mathrm{~S}$ rRNA sequence analysis although, they might be closely related strains. Pseudomonas aeruginosa LMG1242 is a newly isolated type detected in oil polluted soils and is the most active bacterium amongst other isolates in bioemulsification activities of heavy oils. The strains reduced the surface tension of the media well below $30 \mathrm{mN} / \mathrm{m}$, even as low as $23.5 \mathrm{mN} / \mathrm{m}$ when grown in heavy diesel oil. However, their activities were somewhat reduced when grown in heavier oil (Isofeed). The results also showed that the biosurfactant-producing activities of the consortia were generally greater than that of the isolates. This implies the accumulative effects of the biosurfactant-producing bacteria in the consortium.

\section{ACKNOWLEDGEMENTS}

This research was funded by the Material and Energy Research Center under project NO. 528904.

\section{REFERENCES}

Abalos, A., Vinas, M., Sabate, J., Manresa, M. J., \& Solanas, A. M. 2004. Enhanced biodegradation of Casablanca crude oil by a microbial consortium in presence of a rhamnolipid produced by Pseudomonas aeruginosa AT10. Biodegradation 115: 249-269.

Amaral, P. F. F., Coelho, M. A. Z., Marrucho, I. M., \& Coutinho, J. A. P. 2010. Biosurfactants from yeasts: characteristics, production and application. In: Biosurfactants. Ed. Sen, R. pp. 236-249. Springer Science.

Aparna, A., Srinikethan, G., \& Hegde, S. 2011. Effect of Addition of biosurfactant produced by Pseudomonas sp. on biodegradation of crude oil. 2nd International Conference on Environmental Science and Technology. IPCBEE vol.6. Singapore: IACSIT Press.

Bach, H. \& Gutnick, D. L. 2004. Potential applications of bioemulsifiers in the oil industry. In: Petroleum Biotechnology: developments and perspectives. Eds. Vasquez-Duhalt, R., Quintero-Ramizaro, R. pp. 233-281. Netherlands: Elsevier B.V.

Bannat, I. M. 2000. Potentials for use of biosurfactants in oil spills cleanup and oil bioremediation, oil and hydrocarbon spills
II. In: Eds. Brebbia, C. A., Rodriguez, G. R. WIT Press. ISBN 1-85312-828-7.

Barin, R., Talebi, M., Biria, D., \& Beheshti, M. 2014. Fast bioremediation of petroleum-contaminated soils by a consortium of biosurfactant/bioemulsifier producing bacteria. International Journal of Environmental Science Technology 11: $1701-1710$

Bodour, A. A., Drees, K. P., \& Miller-Maier, R. M. 2003. Distribution of biosurfactant-producing bacteria in undisturbed and contaminated arid Southwestern soils. Applied \& Environmental Microbiology 69(6): 3280-3287.

Bodour, A. A. \& Miller-Maier, R. M. 1998. Application of a modified drop-collapse technique for surfactant quantitation and screening of biosurfactant-producing microorganisms. Journal of Microbiological Methods 32: 273280.

Bushnell, L. D. \& Hass, H. F. 1941. The utilization of certain hydrocarbons by microorganisms. Journal of Bacteriology 41: 653-673.

Cai, T., Wang, X., Wen, W., Zhang, Z., \& Wang, T. 2017. Promotion effect of biosurfactant on heavy-oil biodegradation. Petroleum Science and Technology 35(16): $1692-$ 1698.

Cerón-Camacho, R., Martínez-Palou, R., Chávez-Gómez, B., Cuéllar, F., Bernal-Huicochea, C., Clavel, J. C., \& Aburto, O. 2013. Synergistic effect of alkyl-O-glucoside and cellobioside biosurfactants as effective emulsifiers of crude oil in water, A proposal for the transport of heavy crude oil by pipeline. Fuel 110: 310-317.

Choi, H. J., Kim, M. H. , Cho, M. S., Kim, B. K., Kim, J. Y., Kim, C., \& Park, D. S. 2013. Improved PCR for identification of Pseudomonas aeruginosa. Applied Microbiology Biotechnology 97: 3643-3651.

Christova N., Kabaivanova, L., Nacheva, L., Petrov, P., \& Stoineva, I. 2019. Biodegradation of crude oil hydrocarbons by a newly isolated biosurfactant producing strain. Biotechnology \& Biotechnological Equipment 33(1): 863-872 .

Chrzanowski, L., Owsianiak, M., Wyrwas, B., Aurich, A., Szulc, A., \& Olszanowski, A. 2008. Adsorption of sodium dodecylbenzenesulphonate (SDBS) on Candida maltosa EH 15 influence on cell surface hydrophobicity and n-alkane biodegradation. Water, Air, Soil Pollution 196: 345-353.

Cooper, D. G. 1986. Biosurfactants. Microbiological Sciences 3(5): 145-149.

Cooper, D. G. \& Goldenberg, B. G. 1987. Surface-Active Agents From Two Bacilllus Species. Applied \& Environmental Microbiology 53(2): 224-229.

Cybulski, Z., Dziurla, E., Kaczorek, E., \& Olszanowski, A. 2003. The influence of emulsifiers on hydrocarbon biodegradation by Psedomonacea and Bacillacea strains. Spill Science \& Technology Bulletin 8: 503-507.

Das, K. \& Mukherjee, A. K. 2007. Crude petroleum-oil biodegradation efficiency of Bacillus subtilis and Pseudomonas aeruginosa strains isolated from a petroleum-oil contaminated soil from North-East India. Bioresource Technology 98: 1339-1345.

Desai, J. D. \& Banat, I. M. 1997. Microbial production of surfactants and their commercial potential. Microbiology and Molecular Biology Reviews 61(1): 47-64.

Ghavipanjeh, F., Pazouki, M., Ziaei, Z., \& Hosseinna, A. 2015. Biological conversion of normal chain octadecane by native microbial consortia. Iranian Journal of Chemical Engineering 12 (2): 50-58.

Ghavipanjeh, F., Pazouki, M., Hosseinnia, A., Shayegan, J., Ziaei, Z., Allaverdi, A., \& Salehi, R. 2008. Application of microorganisms in biological cracking of ISOMAX (hydrocraking unit) feed. Project report. Contract NO. 841004, National Iranian Oil Refining and Distribution CO. 
Ghollami, M., Roayaei, M., Ghavipanjeh, F., \& Rasekh, B. 2013. Bioconversion of heavy hydrocarbon cuts containing high amounts of resins by microbial consortia. Journal of Petroleum and Environmental Biotechnology 4(2).

Gudiña, E. J. \& Teixeira, J. A. 2017. Biological treatments to improve the quality of heavy crude oils. In: Eds. Heimann et al. Biodegradation and Bioconversion of Hydrocarbons, Environmental Footprints and Eco-design of Products and Processes. pp. 337-352. Singapore: Springer Science+Business Media

Morikawa, M., Hirata, Y., \& Imanaka, T. 2000. A study on the structure-function relationship of lipopeptide biosurfactants. Biochimica et Biophysica 1488: 211-218.

Mulligan, C. N. 2005. Environmental applications for biosurfactants. Environmental Pollution 133: 183-198.

Nordin, N., Zakaria, M. R., Halmi, M. I. E., Ariff, A. B., Zawawi R. M., \& Wasoh, H. 2013. Isolation and screening of high efficiency biosurfactant-producing bacteria Pseudomonas sp. Journal of Biochemistry Microbiology and Biotechnology 1(1): 25-31.

Nwagumal, I. V., Chikere, C. B., \& Okpokwasili, G. C. 2016. Isolation, screening and identification of biosurfactantproducing bacteria from hydrocarbon-polluted and pristine soils within Ogoniland, Nigeria. British Microbiology Research Journal 15(4): 1-11.

Perfumo, A., Rancich, I., \& Banat, I. M. 2010. Possibilities and challenges for biosurfactants use in petroleum industry. In: Biosurfactants Advances in Experimental Medicine and Biology. Ed. Sen, R. pp. 135-145. New York: Springer.

Rashedi, H., Jamshidi, E, Mazaheri Assadi, M., \& Bonakdarpour, B. 2005. Isolation and production of biosurfactant from Pseudomonas aeruginosa isolated from Iranian southern wells oil. International Journal of Science and Technology 2(2): 121-127.

Rocha, C. A., Gonzalez, D., Iturralde, M. L., Lacoa, U. L., \& Morales, F. A. 2000. Production of oily emulsions emitted by a microbial tenso-active agent. US patent 6060287 .

Rosenberg, E. \& Ron, E. Z. 1999. High and low-molecular-mass microbial surfactants. Applied Microbiology \& Biotechnology 52: 154-162.

Sobri, I. M., Halim, M., Oi-Ming, L., Lajis A. F., Yusof M. T., Effendi M. I. H., Johari W. L. W., \& Wasoh, H. 2018. Emulsification characteristics of rhamnolipids by Psendomonas aeruginosa using coconut oil as carbon source. Journal of Environmental Microbiology and Toxicology 6(1): 7-12.

Souza, E. C., Vessoni-Penna, T. C., \& Oliveira, R. P. S. 2014. Biosurfactant-enhanced hydrocarbon bioremediation: an overview. International Journal of Biodeterioriation and Biodegradation 89: 88-94.

Sugiura, K., Ishihara, M., Shimaauchi, T., \& Harayama, S. 1997. Physiochemical properties and biodegradability of crude oil. Environmental Science \& Technology 31: 45-51.

Wasoh, H., Baharun, S., Halim, M., Lajis A. F., Ariff, A. B., \& OiMing, L. 2017. Production of rhamnolipids by locally isolated Psendomonas aeruginosa using sunflower oil as carbon source. Bioremediation Science and Technology Research 5(1): 1-6.

Youssef, N. H., Duncan, K. E., Nagle, D. P., Savage, K. N., Knapp, R. M., \& McInerney, M. J. 2004. Comparison of methods to detect biosurfactant production by diverse microorganisms. Journal of Microbiological Methods 56: 339_ 347. 